\title{
CLINICAL EVALUATION FOR TREATMENT OF CHRONIC INFLAMMATORY GINGIVAL ENLARGEMENT USING DIODE LASER VERSUS ELECTROCAUTERY GINGIVECTOMY
}

\author{
Ahmed Dardir Mohamed and Lama H. Marssafy
}

\begin{abstract}
Introduction: Management of gingival enlargement starts with conventional periodontal treatment and might be followed by surgical intervention to return the gingiva to its normal anatomical and physiological contour. Gingivectomy can be done by various techniques as laser and electrocautery. Diode laser as a semiconductor transfer electrical energy into light energy allowing easy manipulation of soft tissue. Electrocautery is a controlled, precise application of heat used with carefully designed electrodes.
\end{abstract}

Materials and Methods: A split mouth study design was done on ten patients having bilaterally symmetrical gingival hyperplasia in lower anterior teeth due to chronic inflammatory gingival enlargement. In each patient, gingivectomy was done with diode laser at the right side and electrocautery at the left side.

Results: Intraoperative parameters included haemostasis and duration of surgery which showed no significant difference between both sides while laser showed significant improvement over electrocautery regarding instrument sticking. Postoperative parameters included pain which showed statically significant difference between both sides at $72 \mathrm{hs}$ in favor of electrocautery side, and healing index (HI) which showed no significant difference between both sides at $72 \mathrm{hs}$, one week and one month postoperatively.

Conclusion: Both treatment modalities were efficient in performing gingivectomy however, Electrocautery was superior to diode laser regarding postoperative pain and diode laser has advantage over electrocautery regarding instrument performance and showed better improvement in healing process.

KEYWORD: Gingivectomy; Diode laser; Electrocautery.

* Assistant Professor of Oral Medicine, Oral Diagnosis and Periodontology, Faculty of Oral and Dental Medicine, Ahram Canadian University, Egypt and Umm- Al-Qura University, KSA,

** Assistant Professor of Oral Medicine, Oral Diagnosis and Periodontology, Department of Basic and Clinical Oral Sciences, Collage of Dentistry, Umm Al Qura University, KSA. 


\section{INTRODUCTION}

Gingival tissues enlargements are due to different causes as dental plaque, drugs as (anticonvulsants, immunosuppressants \& calcium channel blockers), underlying systemic disease or local iatrogenic factors. Chronic inflammatory gingival enlargement considered the most common cause of them. Prolonged exposure to bacterial plaque leads to infective cellular infiltration accompanied with edema. Gingival tissues will appear soft and discolored. Management starts with conventional periodontal treatment as scaling and root planning. However, existence of significant fibrotic tissue in the gingival tissues will prevent the adequate required shrinkage. As a result, the conventional treatment wouldn't be enough and a surgical intervention is mandatory to return the gingival to its anatomical and physiological conditions..$^{1-3}$

Gingivectomy is the most common surgical procedure for treatment of gingival enlargements. It is done by excising the unsupported gingival tissue and creating a new gingival margin that is apical to the previous one. Performance of gingivectomy can be done by various techniques as scalpel, lasers, electrosurgical unit and chemicals such as 5\% paraformaldehyde or potassium hydroxide., ${ }^{4,5,7}$

Laser as one of these varieties is a promising treatment modality for management of gingival enlargement with gingivectomy. Different types of laser exists including diode laser, carbon dioxide laser, neodymium-doped yttrium-aluminum-garnet (Nd:YAG) laser and chromium:yttrium-scandiumgallium-garnet. Diode laser as a semiconductor transfer electrical energy into light energy by using solid elements as arsenide, gallium, indium and aluminum. Soft tissue will absorb the light energy emitted from the diode laser greatly while hard tissues as teeth and bones have week absorption of it. Diode laser with wavelength $(810-980 \mathrm{~nm})$ is absorbed by chromophores as melanin and oxyhemoglobin. It allows easy handling of the soft tissue and enhances epithelization and healing.
At the same time generation of heat will cause coagulation and prevent bleeding by sealing the blood vessels..$^{6,8-10}$

Electrocautery or thermal cautery is a controlled, localized application of heat on a soft tissue area that needed to be excised. It is used in various surgical procedures using carefully designed electrodes. It is composed of a heated electrode supplied by direct or alternating current which when applied to the tissues will achieve hemostasis with varying degrees of tissue destruction. The provided hemostasis will allow a clear view of the operative field. 11-13.

The present split mouth study was conducted to clinically compare between using diode laser and electrocautery in gingivectomy during treatment of patients having chronic inflammatory gingival enlargement.

\section{MATERIALS AND METHODS}

A split mouth study design was done in outpatient clinic at faculty of dentistry Umm Ulqurra University. Ten patients ranging from 2845 years old had involved in the study, all were in good systemic health, nonsmoker, and they were suffering from bilaterally symmetrical gingival hyperplasia in lower anterior teeth due to chronic inflammatory gingival disease. Initial therapy was done for 2 months including oral hygiene instruction, periodontal debridment, and the use of chlorhexidine mouthwash $0.2 \%$ twice daily for two weeks. All surgeries were carried out after informing the patient the aim of the study and informed consent was signed. In each patient, diode laser (for the right side) and electrocautery (for the left side) were used for gingivectomy in the lower anterior teeth.

Surgical procedures were performed under local anaesthesia. The gingival hyperplastic tissues on the right side were excised with diode laser (manufactured by Hager \& Werken: Germany) with wavelength of $975 \mathrm{~nm}$ and fibre diameter of 320 micrometre in contact type mode. A power setting of $8 \mathrm{~W}$ was applied in a continuous wave.

On the left side of the lower anterior teeth gingival overgrowth was excised with monopolar 
electrocautery having a power of $50 \mathrm{~W}$ and 1000 $\Omega$ resistance in the cutting mode. Chlorhexidine mouthwash was prescribed postoperatively for oral rinse twice daily to maintain adequate oral hygiene. Ibuprofen $400 \mathrm{mg}$ analgesics three times a day was prescribed when needed. Patients were advised to stay on soft diet for the day of the procedure.

\section{Evaluation of parameters:}

Parameters in this study were divided into two groups, intraoperative and post-operative parameters. Intraoperative parameters included three items. First: Haemostasis or bleeding which was scored: 1 : None -2 : Self limiting - 3: Requiring light pressure -4 : Requiring coagulation - 5: Requiring ligation or Hemoclips. Second: Duration of surgical procedure was measured in minutes in each patient separately for electrocautery side or diode laser side. Third: Instrument performance during the surgical procedure was assessed and scored: 1 : None -2 : Requiring activation of instrument to release tissue -3 : Requiring gentle grasping and removal of tissues from the instrument 4: Requiring extensive force for removal of tissue from the instrument -5 : Tearing tissue when instrument tip is released from application site. ${ }^{14}$

While postoperative parameters consist of another two items including, First: Postoperative pain which was evaluated by 10-point Visual Analog Scale (VAS) at $24 \mathrm{~h}$ and $72 \mathrm{~h}$. It is a horizontal line $10 \mathrm{~cm}$ in length and was classified as follows. Score 0-1 cm- no pain or distress, score 2-3 cm- annoying, score 4-5 cm- uncomfortable, score 6-7 cm- dreadful, score 8-9 $\mathrm{cm}$ - horrible and score $10 \mathrm{~cm}$ - agonizing or unbearable distress. The patients were asked to score pain for both right and left sides separately. ${ }^{15,16}$ Secondly: Wound healing which was assessed clinically at 72 hours, one week and one month using Landry index. ${ }^{17}$ The healing index (HI) scores were based on redness, presence of granulation tissues, bleeding, suppuration, and epithelialization. The score composed from 1-5 with score 1 represent very poor healing while score 5 represents excellent healing of the tissues.

\section{Statistical analysis}

All data were collected in tables and subjected to statistical analysis. They were expressed as mean \pm SD percentage whatever needed. Chi-square test used to compare between tested groups. (significant level was set at 0.05) (IBM SPSS Statistics for Windows, Version 23.0. Armonk, NY: IBM Corp.

\section{RESULTS}

Ten healthy patients diagnosed having bilateral chronic inflammatory gingival enlargement in lower anterior teeth participated in this study. There age ranging from 28-45 years old (mean \pm standard deviation: $33 \pm 5.37$ years). Results of various intraoperative and postoperative parameters evaluated in this study were as follows:

\section{Intraoperative parameters}

\section{Haemostasis_or bleeding: Table (1), Graph (I)}

On laser side, there was no bleeding in 6 patients $(60 \%)$ and the bleeding was self-limiting in 4 patients $(40 \%)$. While in the electrocautery side there was no bleeding in 3 patients $(30 \%)$ and bleeding was self-limiting in 7 patients $(70 \%)$. No significant difference between laser and electrocautery regarding haemostasis.

\section{Duration of surgical procedure: Table (2)}

At the laser side the mean time taken for the surgical procedure was $16.29 \min ( \pm 0.7)$, while at the electrocautery side the mean time was $15.74 \mathrm{~min}$ $( \pm 0.67)$. No significant difference exists between them.

\section{Instrument performance: Table (3), Graph (II)}

During the surgical procedure on the laser side 5 patients $(50 \%)$ showed no instrument sticking and 5 patients $(50 \%)$ required gentle grasping for removal of tissues from the instrument. On the other hand, the electrocautery side required gentle grasping to remove tissues from the instrument in all 10 patients (100\%). A significant difference exists between them with p-value (0.01). 
TABLE (1)

\begin{tabular}{|c|c|c|c|c|c|c|}
\hline & & \multicolumn{2}{|c|}{ Diode laser } & \multicolumn{2}{|c|}{ Electrocautery } & \multirow{2}{*}{ p-value } \\
\hline & & $\mathrm{n}$ & $\%$ & $\mathrm{n}$ & $\%$ & \\
\hline \multirow{5}{*}{ Haemostasis } & None & 6 & $60.0 \%$ & 3 & $30.0 \%$ & \multirow{5}{*}{$0.178 \mathrm{NS}$} \\
\hline & Self-limiting & 4 & $40.0 \%$ & 7 & $70.0 \%$ & \\
\hline & Requiring light pressure & 0 & $0.0 \%$ & 0 & $0.0 \%$ & \\
\hline & Requiring coagulation & 0 & $0.0 \%$ & 0 & $0.0 \%$ & \\
\hline & Requiring ligation or Hemoclips & 0 & $0.0 \%$ & 0 & $0.0 \%$ & \\
\hline
\end{tabular}

NS=Non-signifcant,$*=$ significant

TABLE (2)

\begin{tabular}{llllll}
\hline & \multicolumn{2}{c}{ Diode laser } & \multicolumn{2}{c}{ Electrocautery } & p-value \\
\cline { 2 - 5 } & Mean & SD & Mean & SD & \\
\hline Duration of surgical procedure & 16.29 & 0.7 & 15.74 & 0.67 & 0.085 NS \\
\hline
\end{tabular}

NS=Non-signifcant, *=significant

TABLE (3)

\begin{tabular}{|c|c|c|c|c|c|c|}
\hline & & \multicolumn{2}{|c|}{ Diode laser } & \multicolumn{2}{|c|}{ Electrocautery } & \multirow{2}{*}{ p-value } \\
\hline & & $\mathrm{n}$ & $\%$ & $\mathrm{n}$ & $\%$ & \\
\hline \multirow{5}{*}{$\begin{array}{l}\text { Instrument } \\
\text { performance }\end{array}$} & None & 5 & $50.0 \%$ & 0 & $0.0 \%$ & \multirow{5}{*}{$0.01 *$} \\
\hline & $\begin{array}{l}\text { Requiring activation of instrument to release } \\
\text { tissue }\end{array}$ & 0 & $0.0 \%$ & 0 & $0.0 \%$ & \\
\hline & $\begin{array}{l}\text { Requiring gentle grasping and removal of tissues } \\
\text { from the instrument }\end{array}$ & 5 & $50.0 \%$ & 10 & $100.0 \%$ & \\
\hline & $\begin{array}{l}\text { Requiring extensive force for removal of tissue } \\
\text { from the instrument }\end{array}$ & 0 & $0.0 \%$ & 0 & $0.0 \%$ & \\
\hline & $\begin{array}{l}\text { Tearing tissue when instrument tip is released } \\
\text { from application site }\end{array}$ & 0 & $0.0 \%$ & 0 & $0.0 \%$ & \\
\hline
\end{tabular}




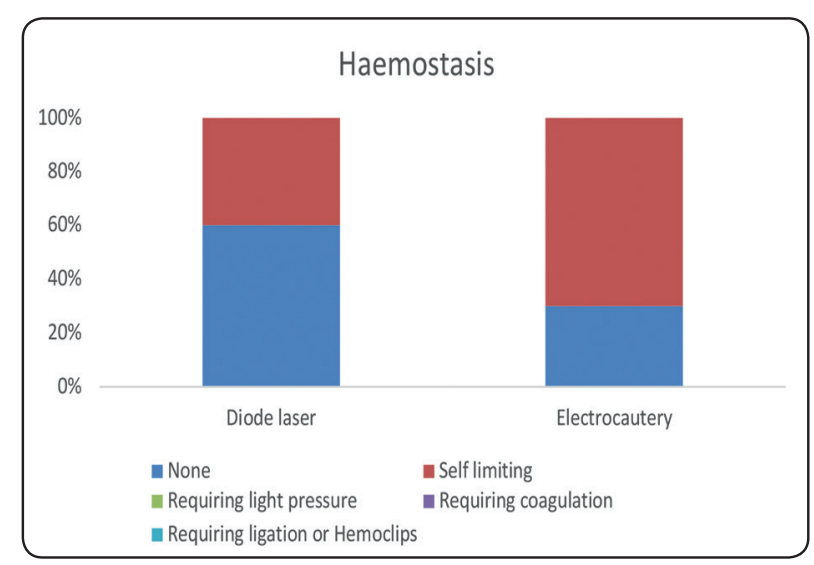

GRAPH (I)

\section{Postoperative parameters:}

\section{Postoperative pain: Table (4) Graph (III)}

At $24 \mathrm{~h}$ the laser side showed 2 patients $(20 \%)$ with annoying pain, 6 patients $(60 \%)$ having uncomfortable pain and 2 patients $(20 \%)$ suffered from dreadful pain. While in the electrocautery side 2 patients (20\%) didn't had any pain, 4 patients (40\%) had annoying pain and 4 patients had uncomfortable pain. However this increased pain in the laser TABLE (4)

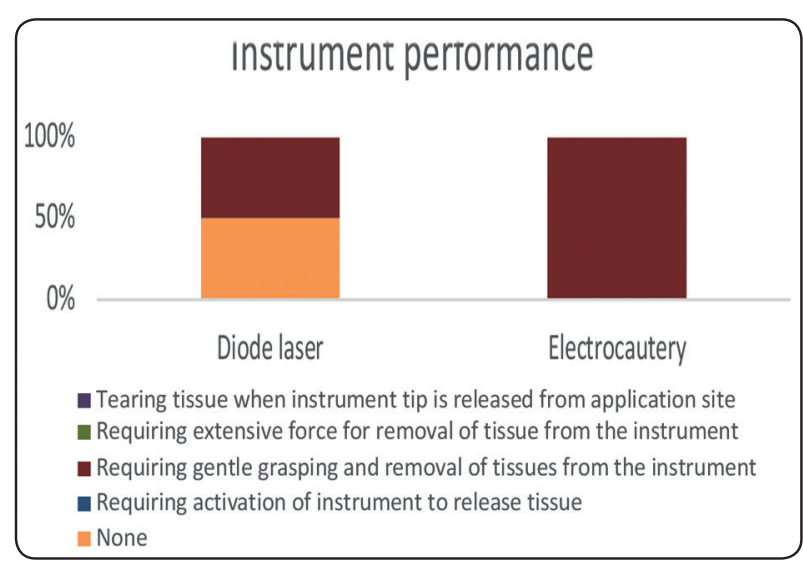

GRAPH (II)

side showed no significant difference with p-value (0.167). At $72 \mathrm{~h}$ still the pain is increased in the laser side over the electrocautery side with 1 patient (10\%) had no pain, 3 patients (30\%) had annoying pain and 6 patients $(60 \%)$ still having uncomfortable pain. In the electrocautery side 8 patients $(80 \%)$ showed no pain and 2 patients (20\%) had annoying pain. So the increased pain in the laser side at $72 \mathrm{~h}$ postoperatively showed statically significant difference with p-value of (0.003).

\begin{tabular}{|c|c|c|c|c|c|c|c|}
\hline & & & \multicolumn{2}{|c|}{ Diode laser } & \multicolumn{2}{|c|}{ Electrocautery } & \multirow[t]{2}{*}{ p-value } \\
\hline & & & $\mathrm{n}$ & $\%$ & $\mathrm{n}$ & $\%$ & \\
\hline \multirow{12}{*}{$\begin{array}{l}\text { postoperative } \\
\text { pain }\end{array}$} & \multirow[t]{6}{*}{$24 \mathrm{~h}$} & no pain or distress & 0 & $0.0 \%$ & 2 & $20.0 \%$ & \multirow[t]{6}{*}{$0.167 \mathrm{NS}$} \\
\hline & & annoying & 2 & $20.0 \%$ & 4 & $40.0 \%$ & \\
\hline & & uncomfortable & 6 & $60.0 \%$ & 4 & $40.0 \%$ & \\
\hline & & dreadful & 2 & $20.0 \%$ & 0 & $0.0 \%$ & \\
\hline & & horrible & 0 & $0.0 \%$ & 0 & $0.0 \%$ & \\
\hline & & agonizing or unbearable distress & 0 & $0.0 \%$ & 0 & $0.0 \%$ & \\
\hline & \multirow[t]{6}{*}{$72 \mathrm{~h}$} & no pain or distress & 1 & $10.0 \%$ & 8 & $80.0 \%$ & \multirow[t]{6}{*}{$0.003 *$} \\
\hline & & annoying & 3 & $30.0 \%$ & 2 & $20.0 \%$ & \\
\hline & & uncomfortable & 6 & $60.0 \%$ & 0 & $0.0 \%$ & \\
\hline & & dreadful & 0 & $0.0 \%$ & 0 & $0.0 \%$ & \\
\hline & & horrible & 0 & $0.0 \%$ & 0 & $0.0 \%$ & \\
\hline & & agonizing or unbearable distress & 0 & $0.0 \%$ & 0 & $0.0 \%$ & \\
\hline
\end{tabular}




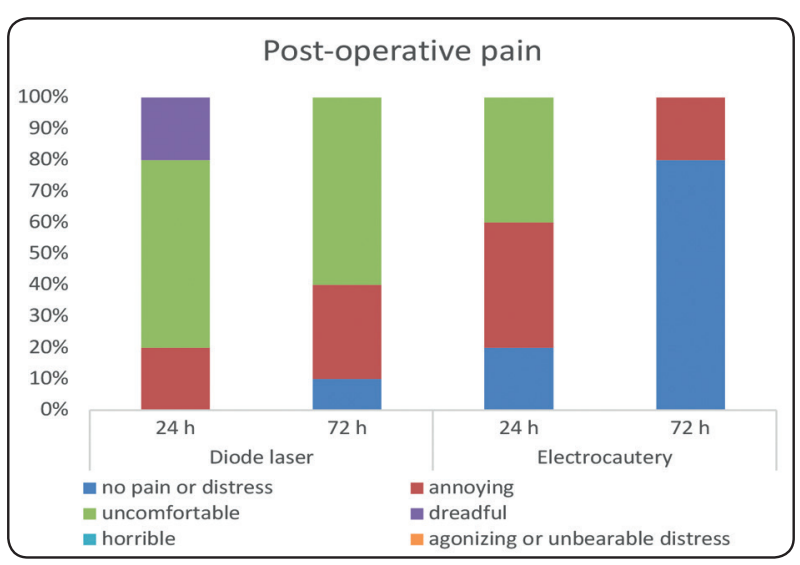

GRAPH (III)

\section{Wound healing: Table (5)}

At $72 \mathrm{~h}$, Charring was observed at laser sides only while fibrinous slough exists at both sides with more obvious presentation at laser side. No statistically difference exists between the laser and the electrocautery sides regarding healing index (HI) with p-value (0.074). On laser side 3 patients (30\%) showed poor presentation and 7 patients appeared with good presentation. The electrocautery side showed 7 patients (70\%) with poor presentation and 3 patients (30\%) showed good presentation. After one week postoperatively, healing was improved in both sides with no statistically significant difference between them with $\mathrm{p}$-value of (0.051). The laser side showed 2 patients with good presentation and 8 patients with very good presentation. While in electrocautery side 3 patients $(30 \%)$ appeared with poor healing scores, 4 patients (40\%) with good score and 3 patients (30\%) with very good healing score. After one month, improvement in healing occurred in both sides with no statistically significant difference between them and $\mathrm{p}$-value of (0.264). At the laser side one patient (10\%) showed very good healing and 9 patients $(90 \%)$ showed excellent healing. The electrocautery side showed 3 patients (30\%) with very good healing and 7 patients (70\%) with excellent healing.

TABLE (5)

\begin{tabular}{|c|c|c|c|c|c|c|c|}
\hline & & & \multicolumn{2}{|c|}{ Diode laser } & \multicolumn{2}{|c|}{ Electrocautery } & \multirow[t]{2}{*}{ p-value } \\
\hline & & & $\mathrm{n}$ & $\%$ & $\mathrm{n}$ & $\%$ & \\
\hline \multirow[t]{15}{*}{ Wound healing } & \multirow{5}{*}{$\begin{array}{l}72 \\
\mathrm{~h}\end{array}$} & Very poor & 0 & $0.0 \%$ & 0 & $0.0 \%$ & \multirow[t]{5}{*}{$0.074 \mathrm{NS}$} \\
\hline & & Poor & 3 & $30.0 \%$ & 7 & $70.0 \%$ & \\
\hline & & Good & 7 & $70.0 \%$ & 3 & $30.0 \%$ & \\
\hline & & Very good & 0 & $0.0 \%$ & 0 & $0.0 \%$ & \\
\hline & & Excellent & 0 & $0.0 \%$ & 0 & $0.0 \%$ & \\
\hline & \multirow[t]{5}{*}{$1 \mathrm{w}$} & Very poor & 0 & $0.0 \%$ & 0 & $0.0 \%$ & \multirow[t]{5}{*}{$0.051 \mathrm{NS}$} \\
\hline & & Poor & 0 & $0.0 \%$ & 3 & $30.0 \%$ & \\
\hline & & Good & 2 & $20.0 \%$ & 4 & $40.0 \%$ & \\
\hline & & Very good & 8 & $80.0 \%$ & 3 & $30.0 \%$ & \\
\hline & & Excellent & 0 & $0.0 \%$ & 0 & $0.0 \%$ & \\
\hline & \multirow[t]{5}{*}{$1 \mathrm{~m}$} & Very poor & 0 & $0.0 \%$ & 0 & $0.0 \%$ & \multirow[t]{5}{*}{$0.264 \mathrm{NS}$} \\
\hline & & Poor & 0 & $0.0 \%$ & 0 & $0.0 \%$ & \\
\hline & & Good & 0 & $0.0 \%$ & 0 & $0.0 \%$ & \\
\hline & & Very good & 1 & $10.0 \%$ & 3 & $30.0 \%$ & \\
\hline & & Excellent & 9 & $90.0 \%$ & 7 & $70.0 \%$ & \\
\hline
\end{tabular}

$\mathrm{NS}=$ Non-signifcant, ${ }^{*}=$ significant 


\section{(CASE 1)}

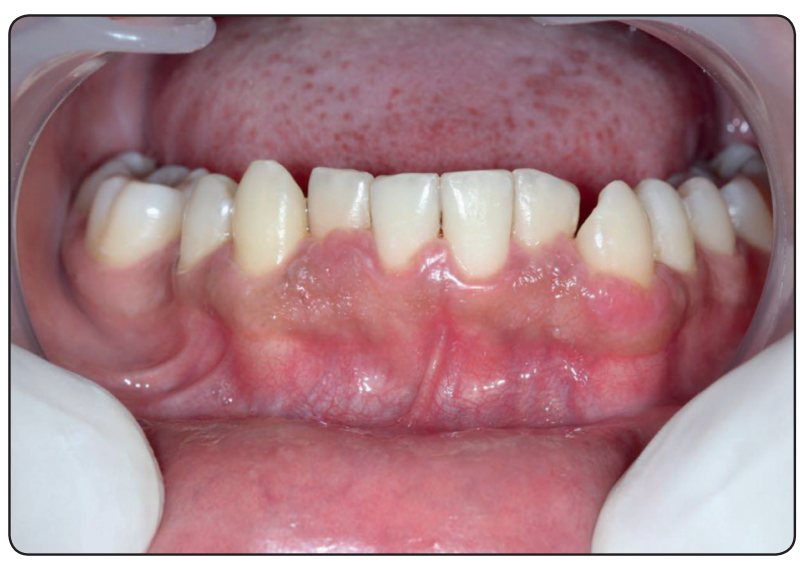

Fig. (1) Pre-operative photograph symmetrical gingival hyperplasia in the lower anterior teeth.

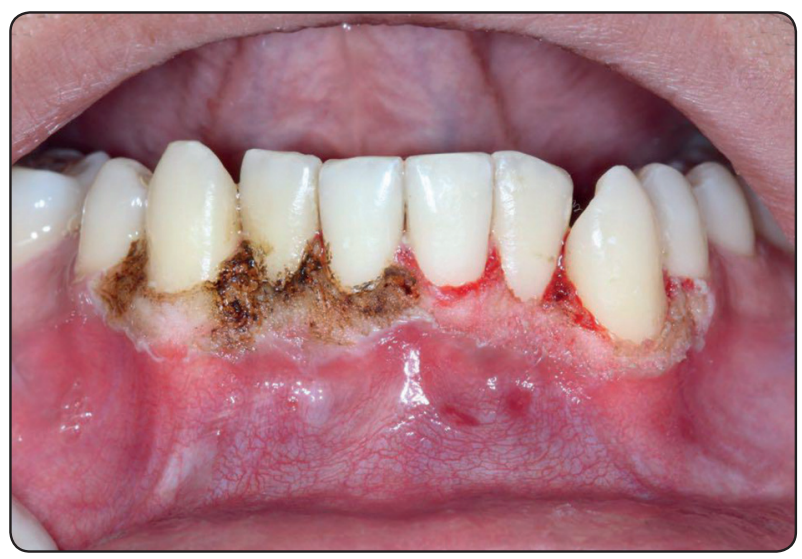

Fig. (2) Immediate gingivectomy using diode laser on the right side and electrocautery on the left side

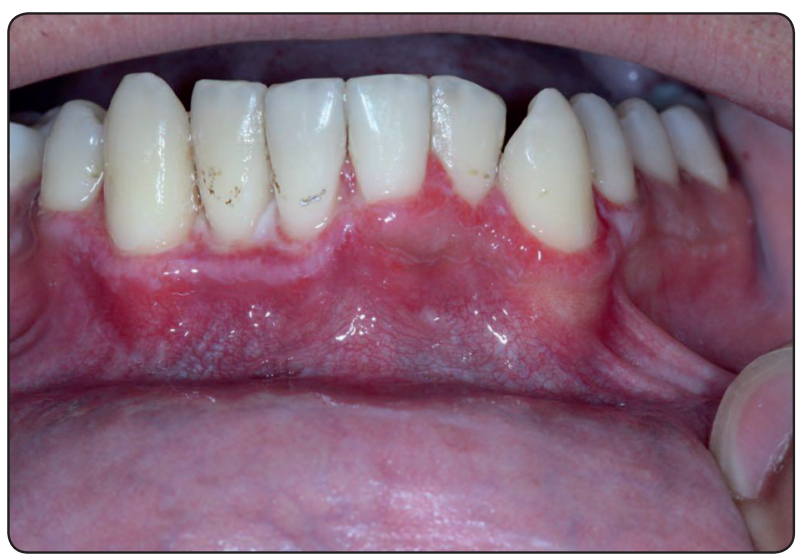

Fig. (3) One week post-operative photographs.

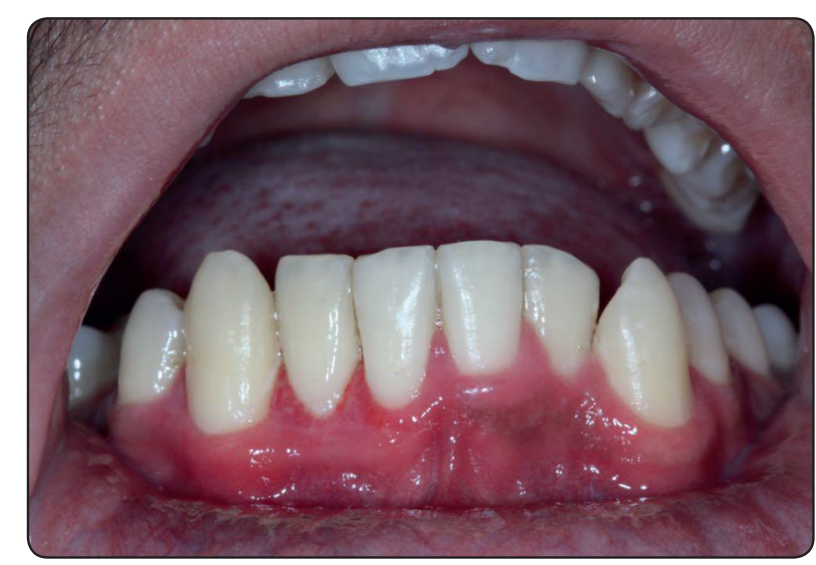

Fig. (4) One month post-operative photographs.

(CASE 2)

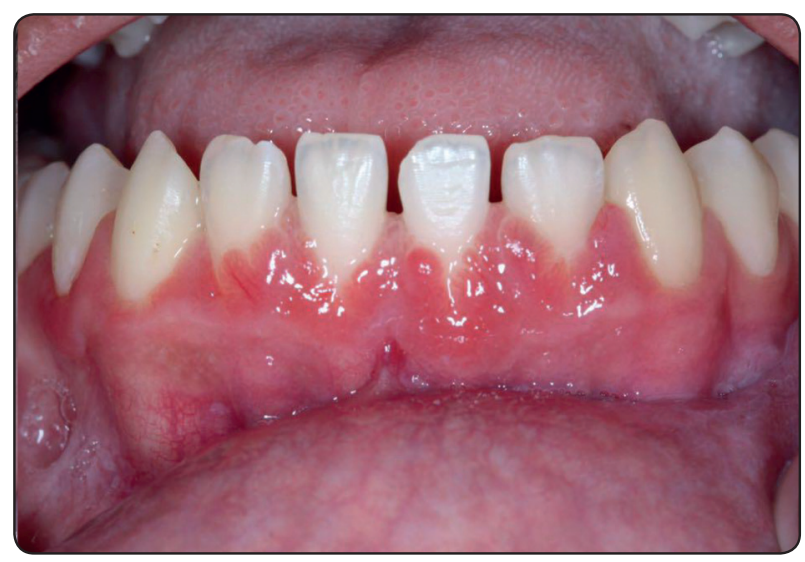

Fig. (5) Pre-operative photograph symmetrical gingival hyperplasia in the lower anterior teeth.

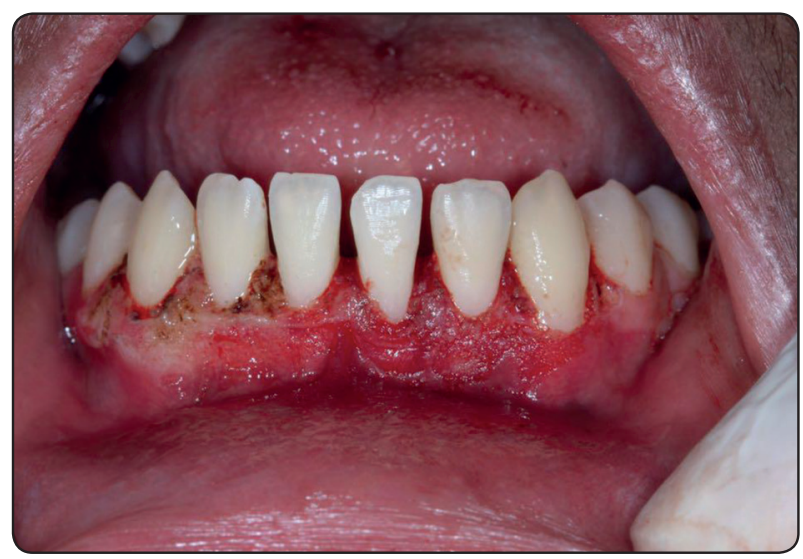

Fig. (6) Immediate gingivectomy using diode laser on the right side and electrocautery on the left side 


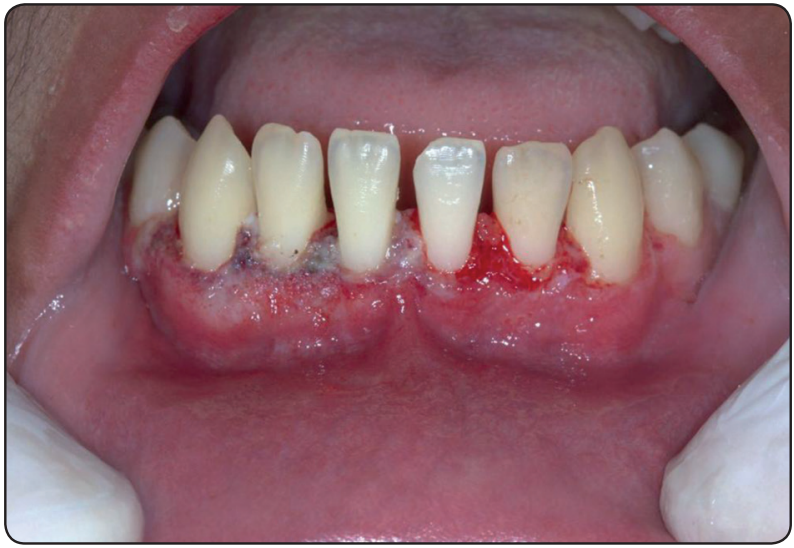

Fig. (7) 72h Gingivectomy using diode laser on the right side and electrocautery on the left side.

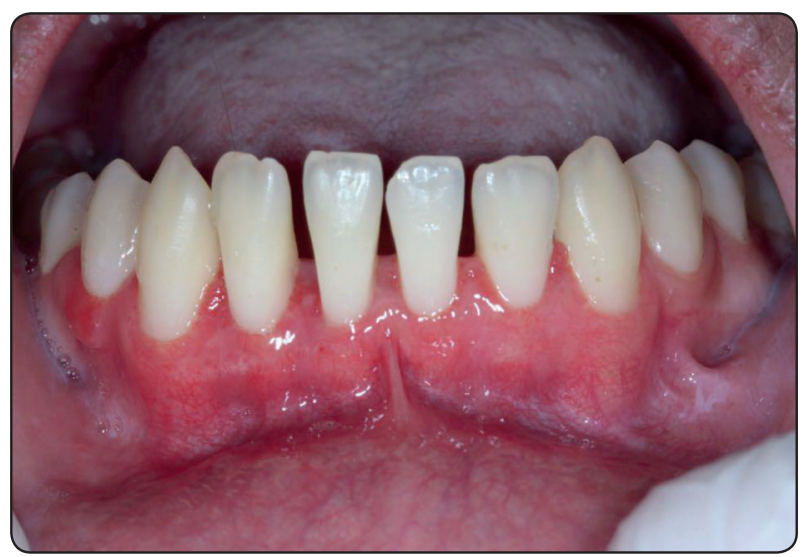

Fig. (9) One month post-operative photographs.

\section{DISSCUSION}

In chronic inflammatory gingival enlargement, surgical excision or gingivectomy are used after obtaining an adequate medical history and performing nonsurgical periodontal therapy to reach functional and esthetical demands. This split mouth study was conducted to clinically compare between using diode Laser or electrocautery during gingivectomy. The split mouth design was chosen as it decreases the effect of inter-subject factors that may have an influence on the results of the study. ${ }^{18}$ Handling properties in both treatment modalities showed precise cutting and well defined margins accompanied with ease of use. Laser application causes minimal or no bleeding during surgery. It

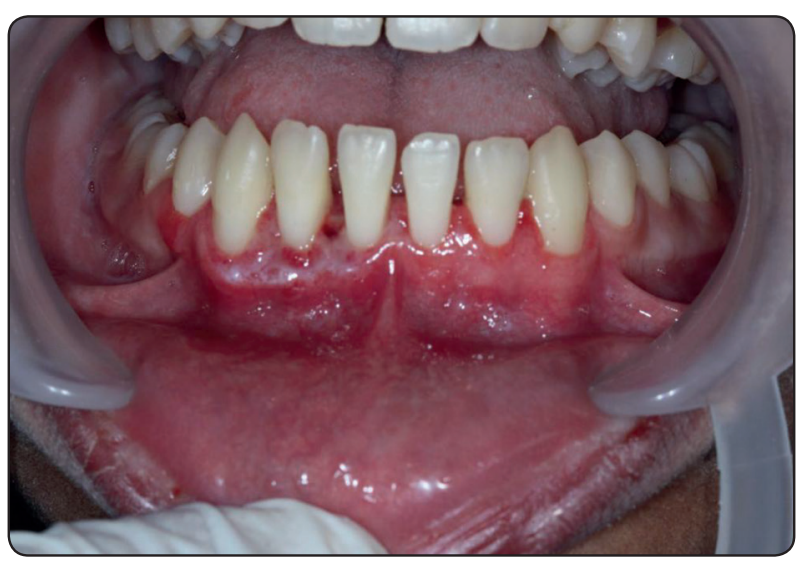

Fig. (8) One week post-operative photographs.

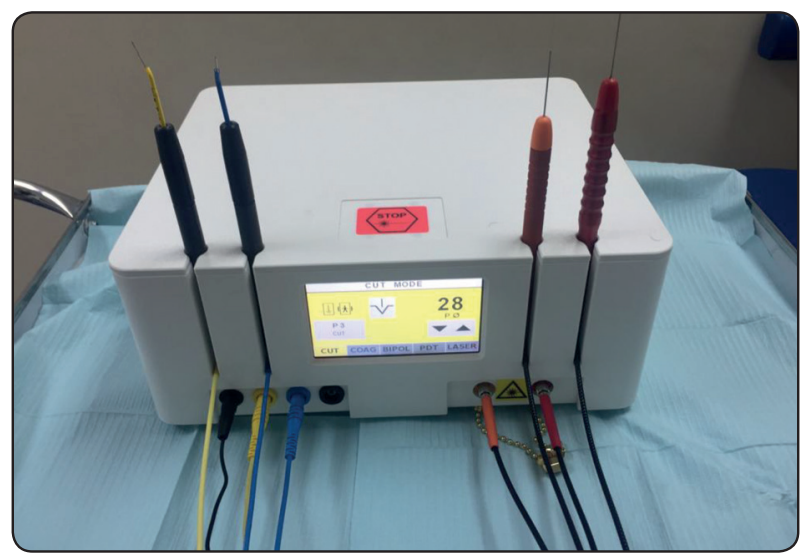

Fig. (10) Dental combination device, Laser plus radio frequency (Manufactured by Hager \& Werken: Germany)

causes enhancement of clotting factor VII formation and changes in molecular structures of collagen of blood vessels from trihelical to randomly helical polymers and coils. This will causes shrinkage in the vessel's collagen, sealing the capillaries and enhancement of hemostasis. ${ }^{19,20,21}$ On the other hand electrocautery provides immediate hemostasis with nearly painless wound healing. ${ }^{22}$ In the present study, a non significant statistical difference exists between laser and electrocautery sides regarding hemostasis through the surgical procedure. All patients showed either none or selflimiting bleeding, which gives an indication that both techniques were able to form good hemostasis. Duration of surgery was measured separately for 
each side in each patient. Insignificant difference exists between mean of both sides, $16.29( \pm 0.7)$ $\min$ at the laser side and $15.74( \pm 0.67) \mathrm{min}$ at the electrocautery side.

Significant difference exists between laser and electrocautery regarding instrument performance. In laser side five patients showed no instrument sticking and the other five required gentle grasping for removal of tissues from the instrument, while all patients in electrocautery sides showed tissue sticking to the instrument tips which required gentle grasping for removal. This is in contrast to the results of Kumar et al $2015^{23}$, who found more tissue sticking on laser side than electrocautery side with easier cutting procedure. However this occurs with cases having thick and deep overgrown tissues, while in less thick tissue cases laser was much easier to use with less sticking on its tip. Postoperative pain was measured twice after 24 and $72 \mathrm{hs}$. In both times electrocautery gingivectomy showed an advantage over laser due to less postoperative pain. However this difference was statistically insignificant at $24 \mathrm{~h}$ and statistically significant at $72 \mathrm{~h}$. Pain was controlled in all patients by taken (Ibuprofen 400mg tds). Similarly, Kumar et al $2015^{23}$ in his study showed higher pain score in laser side over electrocautery side with an insignificant difference between them. On the other hand, Salawe et al $2012^{24}$ found minimal postoperative pain after using diode laser to perform oral biopsy. Also Akram et al 2017, reported less postoperative pain in laser gingivectomy compared with conventional gingivectomy and they attributed this to the heat generated by laser that may inhibit the pain receptors. ${ }^{25}$

In this study, fibrinous slough appears at $24 \mathrm{~h}$ and one week postoperatively more obviously at laser treated sides than at the electrocautery sides. However, the fibrinous slough disappeared from all sites during one month examination. Charring or carbonization was observed in all laser sides postoperatively and did not exist at the electrocautery sides. This might be due to the difference in temperature achievement between both techniques. Electrocautery found to have a lower temperature than laser therapy resulting in no carbonization at the site of tissue removal with less cell disruption. ${ }^{26,27}$ Evaluation of wound healing during this study was done by healing index that was introduced by Landry et al $1988{ }^{17}$. This index was used in evaluation of healing for different periodontal or maxillofacial surgery. ${ }^{28,29,30}$ Its scoring criteria depends on bleeding, redness, existence of granulation tissues, suppuration and epithelialization. No statistical significant difference in this study exists regarding healing index in both laser and electrocautery sides at either $72 \mathrm{~h}$, one week or one month postoperatively. However, healing scores throughout the follow up period was in favor of laser therapy sides. These results agree with the results reported by Kuram et al $2015^{23}$ who found no significant differences between laser and electrocautery gingivectomy groups regarding wound healing at $24 \mathrm{~h}, 72 \mathrm{~h}, 1,2$, 4 weeks postoperatively. However, fibrinous slough and charring exist in both groups with more charring present at the laser sides. In addition, Funde et al 2015 reported that laser has more advantages over the electrocautery for treatment of drug induced gingival over growth, however, they mentioned that scalpel remains the gold standard treatment modality and both laser and elecrtocautery had delayed healing which was attributed to the damage caused by the lateral heat production. ${ }^{31}$

To conclude, within the limitation of this study, both treatment modalities diode laser and electrocautery were efficient in performing gingivectomy for chronic inflammatory gingival enlargement and obtaining adequate hemostasis. Electrocautery were superior to diode laser regarding postoperative pain. However, diode laser has advantage over electrocautery in tissue sticking allowing easier instrument performance. Wound healing process was statistically equivalent in both treatment modalities with better improvement in healing appeared at laser side throughout the healing process. 


\section{REFERENCES}

1. Santosh Hunasgi, Anila Koneru, M Vanishree, and Vardendra Manvikar Assessment of reactive gingival lesions of oral cavity: A histopathological study. J Oral Maxillofac Pathol. 2017; 21(1); Jan-Apr.

2. Newman MG, Takei H, Klokkevold PR, Carranza FA. Carranza'a Clinical Periodontology. 9th ed. Philadelphia: Saunders; 1996. p. 754.

3. Pradeep Shukla, Varun Dahiya, Prerna Kataria, and Shreya Sabharwal. Inflammatory hyperplasia: From diagnosis to treatment. J Indian Soc Periodontol. 2014; Jan-Feb; 18(1): 92-94.

4. Camargo PM, Carranza FA, Pirih FQ, Takei HH. Treatment of gingival enlargement. In: Newman MG, Takei HH, Klokkevold PR, Carranza FA, editors. Carranza's Clinical Periodontology. 12th ed. Philadelphia: W.B. Saunders and Company; 2015. pp. 587-92.

5. Takei HH, Carranza FA, Shin K. Gingival surgical techniques. In: Newman MG, Takei HH, Klokkevold PR, Carranza FA, editors. Carranza's Clinical Periodontology. 12th ed. Philadelphia: W.B. Saunders and Company; 2015. pp. 576-81.

6. Ruchi G., Shaleen K., Madhu S. R., Mishthu S.: Management of massive peripheral ossifying fibroma using diode laser. J Indian Soc Periodontol. 2019 Mar-Apr; 23(2): 177-180.

7. Mosby's Dental Dictionary, 2nd edition, 2008 Elsevier.

8. Akbulut N, Kursen E, Tumer M, et al. Is the 810-nm diode laser the best choice in oral soft tissue therapy? Eur J Dent 2013;7:207-213.

9. Ajkram H. M., Ali O. H., Omran N. K., Ali A. O.: Diode Laser Versus Scalpel Gingivectomy. Biomedical \& Pharmacology Journal. 10(4), 1799-1804, 2017.

10. Ozcelik O., Cenk H. M., Kunin A., Seydaoglu G.: Improved wound healing by low-level laser irradiation after gingivectomy operations: a controlled clinical pilot study. J Clin Periodontol; 35: 250-4, 2008.

11. Pollock S.V., Bolognia J.L., Jorizzo J.L., Rapini R.P.: Dermatology Mosby Elsevier, 2008. 2nd edition: Ch 140.

12. Silverman E.B., Read R.W., Boyle C.R., Cooper R., Miller W.W., McLaughlin R.M.: Histologic comparison of canine skin biopsies collected using monopolar electrosurgery, $\mathrm{CO} 2$ laser, radiowave radiosurgery, skin biopsy punch and scalpel. Vet Surg 2007;36:50-6.
13. Raghavan R., Shajahan P.A., Koruthu A., Sukumar B., Nair A., Divakar K.P. Second stage surgery: A clinical case report comparing efficacy of laser and electrocautery. Int. J. of Dent. Res.; 2(1): 26-28, 2014.

14. Kumar P., Rattan V., Rai S.:Comparative evaluation of healing after gingivectomy with electrocautery and laser. J. of Oral Biology and Craniofacial Research. 5, pp. 6974,2015 .

15. Hjerrnstad M.J., et al. Studies comparing numerical rating scales, verbal rating scales, and visual analog scales for assessment of pain intensity in adults: a systematic literature review. J Pain Symptom Manage; 41(6):1073-1093, 2011.

16. Musa F.M., Awazli L.G., Alhamdani F.: Gingival enlargement management using diode laser $940 \mathrm{~nm}$ and conventional scalpel technique ( A comparative study). Iraq J. Laser, Part B, Vol. 16, pp.1-9, 2017.

17. Landry RG, Turnbull RS, Howley T. Effectiveness of benzydamyne $\mathrm{HCl}$ in the treatment of periodontal postsurgical patients. Res Clin Forum. 1988;10:105-18.

18. Lobo TM, Pol DG. Evaluation of the use of a 940nm diode laser as an adjunct in flap surgery for treatment of chronic periodontitis. J Indian Soc. Periodontol. 2015;19: 43-48.

19. Vescovi P, Corcione L, Meleti M, Merigo E, Fornaini C, Manfredi M, et al. YAG laser versus traditional scalpel. A preliminary histological analysis of specimens from the human oral mucosa. Lasers Med Sci;2010; 25: 685-91.

20. Stubinger S, Saldamli B. Soft tissue surgery with the diode laser-theoretical and clinical aspects. Schweiz Monatsschr Zahnmed, 2006; 116: 812-820.

21. Guy A, Charles C: Laser applications in oral and maxillofacial surgery. Chapter 2 photobiology of laser on oral and maxillofacial surgery. 1997; Pp 32-28.

22. Funde S, Baburaj MD, Pimpale SK. Comparison between laser, electrocautery and scalpel in the treatment of druginduced gingival overgrowth: A case report. IJSS Case Reports \& Reviews. 2015; 1(10): 27-30.

23. Kumar P, Rattan V, Rai S: Comparative evaluation of healing after gingivectomy with electrocautery and laser. $\mathrm{J}$ of Oral Biology and Craniofacial Research. 2015; 5: 69-74.

24. Shalawe W S, Ibrahim Z A, Sulaiman AD. Clinical comparison between diode laser and scalpel incisions in oral soft tissue biopsy. Al- Rafidain Dent J. 2012; 12(5): 337-343. 
25. Akram H M, Ali O H, Omran N K, Ali A O. Diode laser versus scalpel gingivectomy. Biomedical \& Pharmacology Journal. 2017; 10(4): 1799-1804.

26. Romanos G, Nentwig G. Diode laser $(980 \mathrm{~nm})$ in oral and maxillofacial surgical procedures: Clinical observations based on clinical applications. J Clin Laser Med Surg. 1999; 17:5.

27. Romanos G, Nentwig G. Diode laser $(980 \mathrm{~nm})$ in oral and maxillofacial surgical procedures: Clinical observations based on clinical applications. J Clin Laser Surg. 1999; 17:5.

28. Jankovic SM, Zoran AM, Vojislav LM, Bosidar DS, Kenny BE. The use of platelet-rich plasma in combination with connective tissue grafts following treatment of gingival recessions. Perio. 2007; 4: 63-71.

29. Alissa R, Esposito M, Horner K, Oliver R. The influence of platelet-rich plasma on the healing of extraction sockets: An explorative randomized clinical trial. Eur J Oral Implantol. 2010; 3:121-34.

30. Pippi R. Post-surgical clinical monitoring of soft tissue wound healing in periodontal and implant surgery. Int. J Med Sci. 2017; 14: 721-8.

31. Funde S, Baburaj MD, Pimpale SK. Comparison between laser, electrocautery and scalpel in the treatment of druginduced gingival overgrowth: A case report. IJSS. 2015; 1(10): 27-30. 